\title{
Evaluating the link between Corporate Social Responsibility (CSR) and Employee Engagement: Evidence from Selected Commercial Banks of Bangladesh
}

\author{
Rifat Parveen Bokhari \\ Assistant Professor, School of Business, Ahsanullah University of Science and Technology \\ !41-142 Love Road, Tejgaon I/A, Dhaka-1208, Bangladesh
}

\begin{abstract}
Now a days, researchers and companies are paying increasing attention to corporate social responsibility (CSR) initiatives. So, theobjective of this article is to evaluate the link between Carroll,'s(1991)pyramid of CSR activities like economic responsibilities, legal responsibilities, ethical responsibilities and philanthropic responsibilities, companies CSR activities and employee engagement. Most of the research work has done on different group of stakeholdersand this article has given concentration on employees. For collecting the data, a survey was done among 350 employees from 10 public commercial banks of Bangladesh. For analyzing the data, the study has used Confirmatory Factor Analysis and Structural Equation Model to test the goodness of fit and path co-efficient to assess the hypothesis. The result of the analysis suggest that economic responsibilities, legal responsibilities, ethical responsibilities and philanthropic responsibilities are positively associated with company'stotal CSR activities and company's CSR activities are positively related with employee engagement. This studyhas done on tenconventional banks of Bangladesh which are performing their CSR operations very strongly; therefore, future research can be done on extended number of banks or other companies. This article could help the business executives to engage their employees by giving emphasize ontheir CSRprograms. So, companies can increase their CSR activities to engage talent pool for achieving competitive advantage.
\end{abstract}

Keywords: Company's total Corporate Social Responsibility (CSR), EmployeeEngagement,Economic Responsibilities, Legal responsibilities, Philanthropic responsibilities, Ethical responsibilities, Social IdentityTheory, Commercial Banks.

DOI: $10.7176 / \mathrm{EJBM} / 11-33-04$

Publication date: November $30^{\text {th }} 2019$

\subsection{Introduction}

Corporate Social Responsibility has gained increasing consideration by the different researcher (Lee, Kim, Lee, and $\mathrm{Li}, 2012$ ) and it becomes a prevalent concept in the global research and market place (Carroll and Shabana, 2010). Rahman (2013) said that banking area is playing the most important part to make draw on CSR as a link between business and development and it is proved that banks' CSR programmes are their significant involvement to development of the society. He said programs and practices of CSR by the bank not only improve the standard but also transfigure the socially actions. It was found that CSR positively impacts employee turnover, recruitment, Satisfaction, retention, loyalty and commitment (Heslin and Ochoa, 2008; Aguilera, R.V., Rupp, D.E., Williams, C.A. and Ganapathi, J. (2007), and, therefore, employers may be able to use the firm's CSR profile as a device toenhance employee engagement. Evidence from the research work, it has demonstrated that corporate social responsibility measured as a one of the foremost drivers of employee engagement.Employees are vital resources for any organization like bank. There are 62 banks are operating business inBangladesh. The size of the employees is increasing every year. To enhance and attract human resource, companies are turning for conception different strategic programs to engage and to create committed workers (Ologbo and Sofian, 2013). Bakker and Schaufeli, (2004) defined that work engagement is a state of mind that is work related fulfilling and positive environment.

Both in academic research and business dominion, CSR develop into a progressively more strategic issue (Lee, 2008). For addition to this, the main focusof the study on what is the present scenario of CSR practices in selected commercial banks in Bangladesh, how these activities differ from Carroll Pyramid of CSR activities and how total CSR activitiesengage the employees by using Social Identity Theory. Carroll's (1979) Pyramid of CSR defined that the total corporate social responsibility (CSR) of business occupy the simultaneous fondness of the companies legal, ethical, economical and philanthropic responsibilities. For answering these questions, it has designed an inductive study based on annual report -FY-2018from ten commercial banks of Bangladesh.After a literature review of CSR studies in the different developing country contexts, the author provides background information related to CSR practices by the commercial banks of Bangladesh. Corporate Social Responsibility (CSR) isanotion that has paying attention worldwide and acquired a new significance. Nowdays, most of the companies choose to behave more responsibly in the absence of legal requirements.

Prior research work showed that Companies CSR activities are positively associated with employee motivation, retention, trust, commitment employee morale, engagement employee satisfaction (Turban and Cable, 
2003; Brammer. et.al, 2007; Turban and Greening, 1997, Aguileraet.al, 2007; Heslin and Ochoa, 2008; Strautmanis,2008; Viswesvaran, Deshpande, \& Milan, 2004; Melynnyte and Ruzevicius, 2008).Furthermore, a few studies whichexamine the impact of prospective employees' perception of CSR on varied outcomes likesorganizational attractiveness and reputation (Greening and Turban, 2000; Turban andGreening, 1997. For measuring the Impact of CSR on employeeengagement, most of the studies are done in Western context and it has given that lack of knowledge about CSR practices in developing countries (Jamali , D.,\&Mirshak, R.,2007). For developing the research significance, it has chosen two ways e.g. first: prior studies shown positive linkage between perceived CSR and employee engagement and second, Carroll's four dimensions of CSR which constitute total CSR of the organization by social identify theory).Social Identity Theory means a satisfactory feeling of individuality from affiliation with organization for its valued highlighted and activities For establishing this idea, the author has chosen Structural Equation Model to assess the link between aforementioned construct which is more ample and narrative (Lin,2010).From Prior research work, it is trying to find out the present status of CSR practices of selected commercial banks of Bangladesh in FY-2018; to make a comparison with Carroll Pyramid of Corporate Social Responsibilities and bank's CSR approaches, and to evaluate the link between CSR practices and Employee Engagement.

\subsection{TheoreticalBackground}

3.1Present status and approaches of CSR activities by the Public Commercial Bangladesh in 2018

Bangladesh is one of the developing countries in the world map. This paper highlights an empirical study of responses from 10 public commercial banks of Bangladesh among 41 banks regarding their Corporate Social responsibility initiatives as away to engage their employees, while providing an appropriate environment for employee satisfaction by constructing a structural equation model meant to expand HR literature and provide direct implications for organization. The following table stated the present status of bank and CSR approaches used by bank according to their annual report -2018 .

Table-1: Bank Description-FY-2018

\begin{tabular}{|c|c|c|c|c|}
\hline S. & Name of the bank & $\begin{array}{c}\text { Number of } \\
\text { employees } \\
\text { (Above) }\end{array}$ & $\begin{array}{c}\text { Year of } \\
\text { Banking } \\
\text { service }\end{array}$ & Type of bank \\
\hline 1 & Bank Asia Limited & $\mathbf{3 0 0 0}$ & 18 & Commercial Bank \\
\hline 2 & BRAC Bank Limited & $\mathbf{7 0 8 5}$ & 17 & Commercial Bank \\
\hline 3 & Dhaka Bank Limited & $\mathbf{2 1 0 0}$ & 24 & Commercial Bank \\
\hline 4 & Dutch Bangla Bank Limited & $\mathbf{6 0 0 0}$ & 24 & Commercial Bank \\
\hline 5 & Eastern Bank limited & $\mathbf{3 0 0 0}$ & 27 & Commercial Bank \\
\hline 6 & Premier Bank Limited & $\mathbf{2 0 0 0}$ & 19 & Commercial Bank \\
\hline 7 & Prime Bank limited & $\mathbf{3 0 0 0}$ & 24 & Commercial Bank \\
\hline 8 & Pubali Bank Limited & 7204 & 60 & Commercial Bank \\
\hline 9 & South East bank Limited & $\mathbf{2 3 0 0}$ & 24 & CommercialBank \\
\hline 10 & United Commercial Bank Limited & $\mathbf{2 0 0 0}$ & 34 & Commercial Bank \\
\hline
\end{tabular}

Source: Annual Report -2018 
Table-2: Area of CSR Expenditures,FY-2018

\begin{tabular}{|c|c|c|c|c|c|c|c|c|c|c|c|}
\hline & $\begin{array}{l}\text { Area of CSR } \\
\text { activities/Name of the } \\
\text { Bank }\end{array}$ & $\begin{array}{l}\text { BRAC Bank } \\
\text { Limited } \\
\text { (Total. } 111 \\
\text { million } \\
\text { expenditures } \\
\text { on CSR) }\end{array}$ & DBBL & $\begin{array}{l}\text { Bank Asia } \\
\text { Limited } \\
\text { (Total. } \\
126.91 \\
\text { million } \\
\text { expenditures } \\
\text { on CSR) }\end{array}$ & $\begin{array}{l}\text { UCBL } \\
\text { (Not } \\
\text { mention } \\
\text { their } \\
\text { expenditures } \\
\text { on CSR) }\end{array}$ & $\begin{array}{l}\text { Prime } \\
\text { Bank } \\
\text { Limited }\end{array}$ & $\begin{array}{l}\text { Dhaka } \\
\text { Bank } \\
\text { Limited } \\
\\
\text { (Tk. } \\
6.34 \\
\text { crore) }\end{array}$ & $\begin{array}{l}\text { Premier } \\
\text { Bank } \\
\text { Limited } \\
\text { (Tk. } \\
\begin{array}{l}\text { Total.18.26 } \\
\text { crore) }\end{array}\end{array}$ & $\begin{array}{l}\text { South East } \\
\text { Bank } \\
\text { Limited } \\
\text { (Total. } \\
208.53 \\
\text { million } \\
\text { expenditure } \\
\text { on CSR) }\end{array}$ & $\begin{array}{l}\text { Pubali } \\
\text { Bank } \\
\text { Limited }\end{array}$ & $\begin{array}{l}\text { Standard } \\
\text { Bank } \\
\text { Limited } \\
\text { (Total. } 11.48 \\
\text { million } \\
\text { expenditures } \\
\text { on CSR) }\end{array}$ \\
\hline 1 & Education & $60 \%$ & 544.7 & $30.91 \%$ & Mention & Mention & & 5.08 & Mention & Mention & 0.44 \\
\hline 2 & Health & $40 \%$ & $\begin{array}{l}99.5 \\
\text { million }\end{array}$ & $.65 \%$ & Mention & yes & $\begin{array}{l}\text { Tk.1.1 } \\
\text { crore }\end{array}$ & 0.01 & Mention & $\begin{array}{l}\text { Tk. } 12 \\
\text { crore }\end{array}$ & 0.08 \\
\hline 3 & Disaster Management & Yes & $\begin{array}{l}76.5 \\
\text { million }\end{array}$ & $21.38 \%$ & Mention & Mention & $\begin{array}{l}\text { Tk. } 5.00 \\
\text { crore }\end{array}$ & 13.12 & Mention & & 10.21 \\
\hline 4 & Environment & Yes & Mention & & Mention & Mention & & $\begin{array}{l}\text { Not } \\
\text { mention } \\
\text { any cost }\end{array}$ & 6.9 million & Mention & 0.00 \\
\hline 5 & Sports & Yes & Yes & $5.7 \%$ & Mention & Mention & & Mention & Mention & Mention & Not mention \\
\hline 6 & Art \& culture & Yes & Yes & $.92 \%$ & Mention & Mention & & Mention & Mention & Mention & 0.59 \\
\hline 7 & $\begin{array}{l}\text { Socio economic } \\
\text { development }\end{array}$ & Yes & $\begin{array}{l}\text { Taka } \\
859.99 \\
\text { million } \\
\end{array}$ & Not mention & Mention & Mention & $\begin{array}{l}\text { Tk. } 24 \\
\text { lac }\end{array}$ & Mention & Mention & Mention & 0.00 \\
\hline 8 & $\begin{array}{l}\text { Income generating } \\
\text { Activities for } \\
\text { underprivileged } \\
\text { population }\end{array}$ & Yes & & Not mention & Not mention & Mention & Mention & mention & Mention & Mention & 0.00 \\
\hline 9 & $\begin{array}{l}\text { Employees welfare, } \\
\text { Healthcare, safety } \\
\text { standards } \\
\text { and Modern working } \\
\text { environment, development, }\end{array}$ & Mention & Mention & Not mention & Mention & Mention & Mention & Mention & Mention & Mention & Not mention \\
\hline 10 & Share Holders Value & Not mention & $\begin{array}{l}\text { Not } \\
\text { mention }\end{array}$ & Not mention & Mention & Mention & Mention & Mention & Mention & Mention & Not mention \\
\hline 11 & Others & Yes & & $40.44 \%$ & & Mention & Mention & 0.05 & & & 0.16 \\
\hline 12. & Green Financing & & $\begin{array}{l}\text { Taka } \\
26,980.44 \\
\text { million } \\
\end{array}$ & Mention & Mention & Mention & Mention & Mention & Mention & Mention & Mention \\
\hline
\end{tabular}

Source: Annual Report -2018

3.2 Comparison with Carroll Pyramid of CSR activities to selected commercial banks CSR activities, FY2018

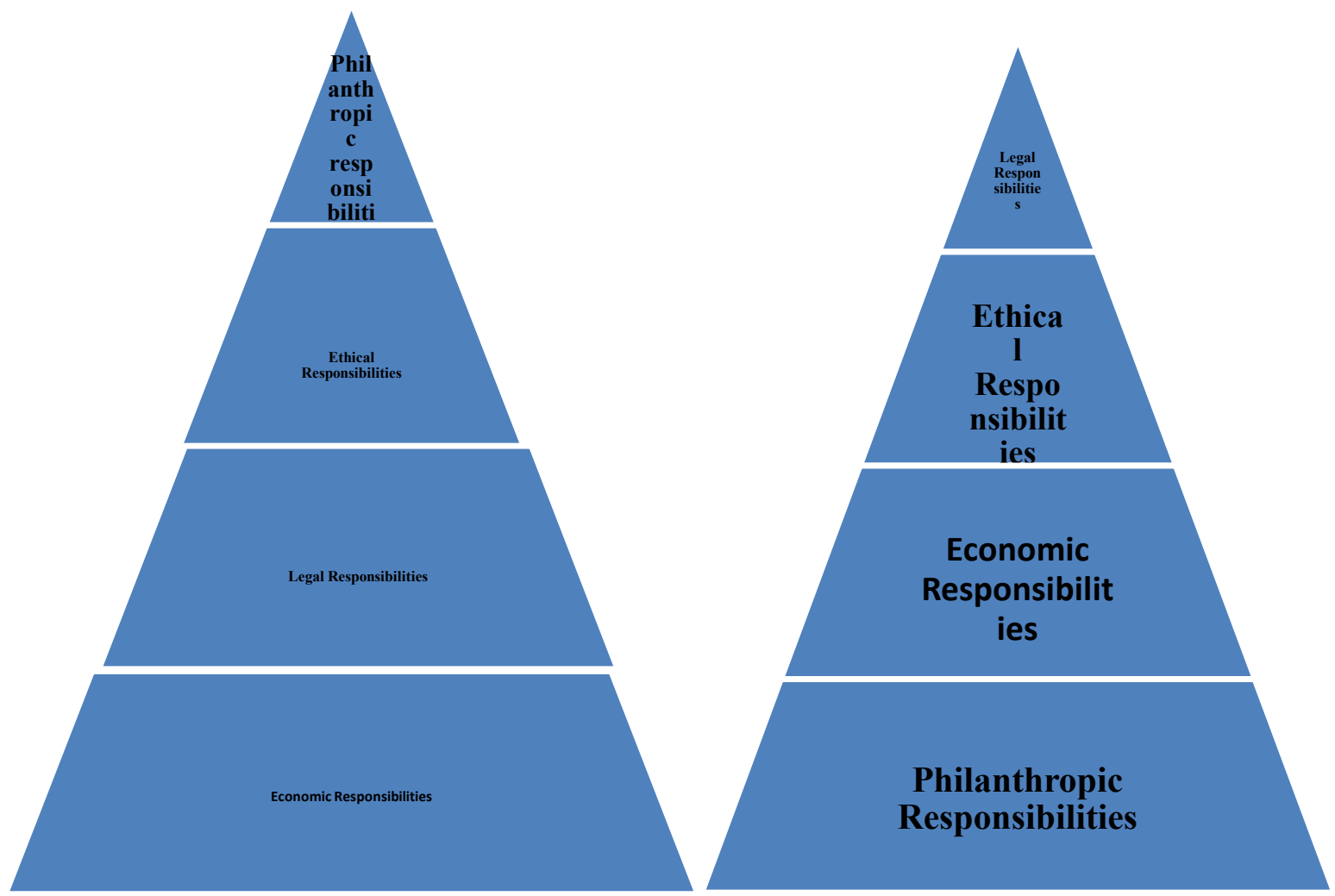

Fig-1: The Pyramid of CSR by Carroll, 1991 Fig: Revising CSR Model 
From the summary of Table-2, the author has observed that most of the banks are taking CSR initiatives for the philanthropic, economic, legal and ethical responsibilities. They have utilized their expenditures on education, health, environment development, culture, sports and employee development, green financing, and other purposes. Among these ten banks, few banks have mentioned their actual expenditures for these activities and others have not mentioned. So, according to the above table, the author creates a figure for CSR Pyramid that revising the Carroll, 1991 CSR modelin the context of Bangladesh based on public commercial banks, annual report-2018.

\subsection{Conceptual Framework and Hypothesis}

\subsection{Conceptual Model and Hypothesis}

The followingfig-2, represents the conceptual model of the relation of six variables: philanthropic responsibilities, ethical responsibilities, legal responsibilities, economic responsibilities, Company's total Corporate Social Responsibilities, and Employee Engagement. It has proven in the academic literature that Organizations CSR initiatives create positive status for an organization and then employees mostly is familiar with the company to boost their self -concepts and build their social identity desires satisfied (Ashforth, \&Mael, 1989; Dutton,Dukerich, \&Harquail, 1994; and Maignan\& Ferrell, 2001). Also added, company which is consisting of cherished features, employees may get hold of an encouraging reaction of identity from affiliation with company. Evidence from SIT, company's reputation and performance enhanced employees' self-confidence and self-esteem to identify themselves by attaching with the organization and fulfill employees belonging needs (Turban et.al, 1997). Based on Carroll's 1979 CSR pyramid and social identity theory, the author has established the following hypothesis and builds this proposed model.

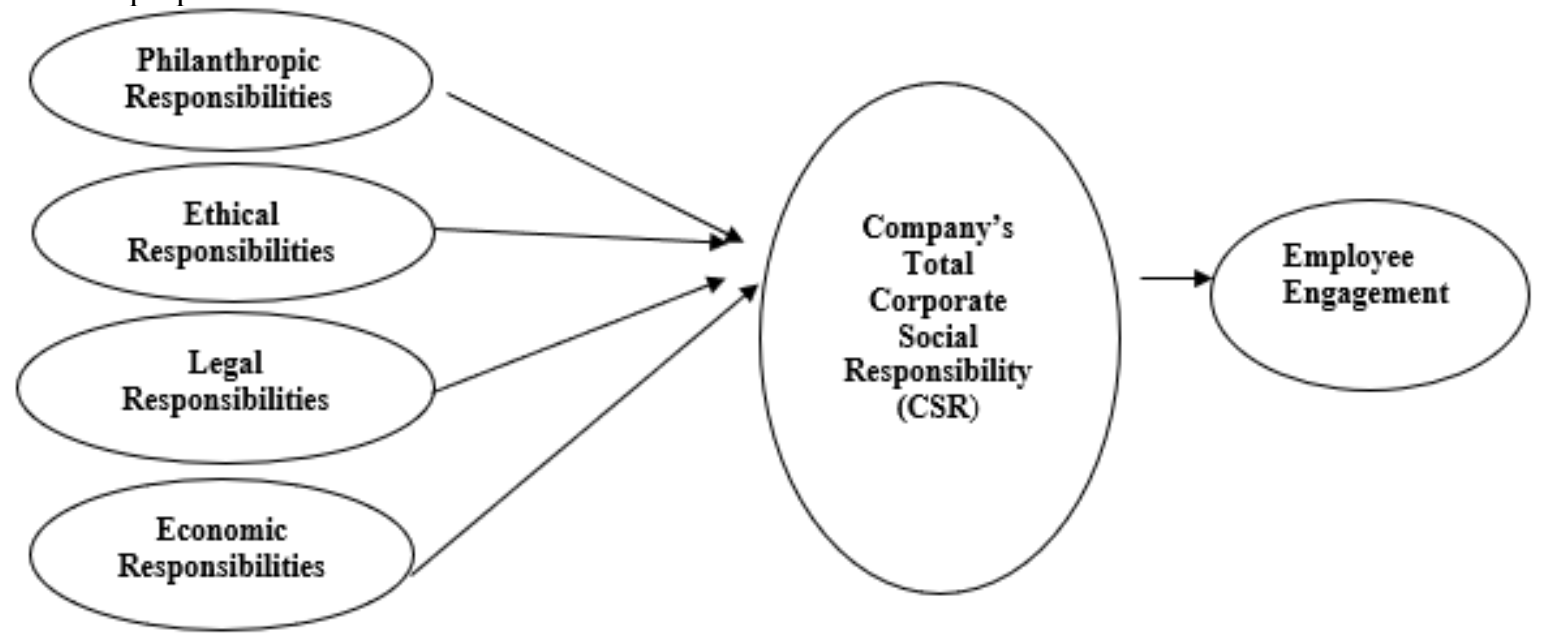

Figure-2: Carroll'sCSR model with employee engagement

\subsection{Corporate Social responsibility}

Recent developed and developing country's researchers, professionals and organization have given prime importance on Corporate Social Responsibility (CSR) .The concept of CSR is extensively recognized ((Madsen \&Ulhoi, 2001; Moon, 2002; Van Marrewijk, 2003; Wheeler, Colbert, \& Freeman, 2003) and the definition of corporate responsibility by Sustainability (2004) is a good design of this convergence and interdependence of terms, describing it "an approach to business that embodies transparency and ethical behavior, respect for stakeholder groups and a commitment to add economic, social and environmental value". Aguilera, R.V., Rupp, D.E., Williams, C.A. and Ganapathi, J. (2007) stated that socially responsible organizations are usually supposed to fair organizations because CSR helps employees to satisfy their psychological need of belongingness because it encourages the social relationships both within the organization and between the organizations. The World Business Council for Sustainable Development (2001) defined that CSR is the commitment of business to contribute to sustainable economic development, working with employees, their families and the local communities.

For developing the conceptual framework, the author has chosen Carroll model of Corporate Social Responsibility because this Pyramid of CSR gives a detailed support for understanding the evolving nature of the firms economic, legal, ethical and philanthropic CSR activities. Crane and Matten (2004) was mentioned in their research wok that Carroll's CSR model has been widely accepted and robust in the literature last 50 years. Further, this model has been empirically tested and supported by the findings (Aupperle, Carroll, \& Hatfield, 1985; Pinkston \& Carroll, 1994) .Carroll, A.B. (1991) suggested in his most well known model that total CSR constitute four kinds of responsibilities: Economic, Legal, Ethical and Philanthropic. He stated that economic responsibilities which is foundation of all,that means be profitable or profit drive that was recognized as the prime incentives for 
the organization; Legal responsibility which means obey the laws and regulations promulgated by federal, state, and local governments. It is codifies ethics that symbolize basic notions of fair operations as recognized by the state. Ethical responsibility which means be ethical what is right, fair and evade harm to stakeholders. It represents those standards, norms and expectations that imitate a distress for shareholders, employees, customer, and the community to keep with respect and protection of stakeholder's moral rights,basically, ethical responsibility as a legitimate CSR component. Last of all, philanthropic responsibility means be good corporate citizen to contribute resources to the community and improve quality of life or to promote human welfare and goodwill. Windsor, (2001) stated in his article that firm total responsibilities encompasses economic and legal responsibilities which is socially required, socially expected responsibility is ethical responsibility and last of all socially desired responsibility is philanthropic responsibility. Visser, W. (2005) has been used Carroll's CSR Pyramid as a framework for vivid analysis and mentioned that this model is most popular model with its four levels of representing the relative importance of economic, legal, ethical, and philanthropic. Bernstein (2000) argues that business should be responsible to stakeholders even if it requires firms to sacrifice some profits. Firms should deal with these conflicting interests and claims in an ethical manner by formulating stakeholders' friendly policies. This is consistent with the assertion of Carroll and Buchholz (2011) that CSR includes economic, legal, ethical, and philanthropic expectations placed on businesses by the society. From the above-mentioned literature, it can be proposed for following hypothesis...

\section{H1 Philanthropic Responsibilities has positive impact on company's CSR initiatives \\ H2 Economic Responsibilities has positive impact Company's CSR initiatives \\ H3 Legal Responsibilities has positive impact on company's CSR initiatives \\ H4 Ethical Responsibilities has positive impact on company's CSR activities}

\subsection{Employee Engagement}

Different researchers, practitioners and organization have given attention on the concept of Employee Engagement. Because, engaged employees are productive and profitable; and also they will be not as much to be absent, and more enthusiastic to work harder for their Organization (Buchanan, 2004; Fleming and Asplund, 2007; Wagner and Harter, 2006).Vance (2006) also suggests that engaged employees generate higher customer satisfaction ratings and increased revenue.

The earliest meaning of engagement found in the academic literature is the one from Kahn $(1990$, p. 700$)$ that defines personal engagement as “the simultaneous employment and expression of a person's 'preferred self' in task behaviors that promote connections to work and to others, personal presence, and active full role performances". Furthermore, the explanation of an employee engagement definition have contributed by different scholar in their work such as Maslach, C., Schaufeli, W.B. and Leiter, M.P. (2001); Harter, J.K., Schmidt, F.L. and Keyes, C.L.M. (2003); Saks (2006) and Czarnowsky (2008).

For the purpose of this paper, the author has chosen the definition given by Bakker and Schaufeli (2008) stated that work engagement can be distinct as a positive, fulfilling, affective-motivational state of work-related well-being. In fact, engagement has emanated from the positive psychology that stresses the need to investigate and find effective applications of positive traits, states and behaviors of employees within organizations (Bakker and Schaufeli, 2008). There are four major approaches of Employee engagement have emerged within the academic perspective such as -(a) Khan's (1990) need satisfying approach explored that the term employee engagement used to describe a worker's association in diverse responsibilities at work. Further explored that how employees' experiences with various work variables (e.g -satisfaction, role clarity, and availability of resources) influenced their experience and involvement with tasks; (b) Maslach et. al.'s (2001) burn-out antithesis approach defining engagement as a "persistent positive affective state ....characterized by high level of activation and pleasure" (p.417);(c) Harter et.al.'s (2002) satisfaction -engagement approach defined the term employee engagement as an "individual's involvement and satisfaction with as well as enthusiasm for work"(p.417), and (d) Saks (2006) multidimensional approach defined the concept employee engagement as a distinct and unique construct consisting of cognitive, emotional, and behavioral... associated with individuals role performance components .

From the four approaches, the author has given concentration on the Saks multidimensional approaches where he stated that employee job engagement and their work engagement. Further added that organization engagement is better that employee job engagement. These two constructs are empirically assessed valid.

\subsection{CSR and Employee Engagement}

CSR stated as the purposeful functions that a company execute its mission and fulfill its apparent obligation to stakeholder's including employees, communities, the external and internal bodies of an organization (Coombs and Holladay, 2012). Greenwood, (2007) stated that employees are prominent stakeholders to whom the organization 
owes a magnificent duty. In any organization like growing service sector most significant stakeholders are employees. [Redington,2005]. Different author give emphasis on consumer, Shareholders and the notion of the importance of the employee as a stakeholder is conspicuously absent from management discussion [De Cieri et al. 2005; Pinnington et al. 2007].So the author is trying to identify literature that CSR activities can engage the existing employees. Chaudhary, R. (2017) found from her empirical study that CSR activities positively associated with employee engagement using snowball sampling and hierarchical linear regression analysis. R Gross and B. Holland (2011) explored in the whitepaper that the positive connection between corporate social responsibility (CSR) and employee engagement. Studies show that CSR is an emerging and increasingly important driver of employee engagement in the work place. For added to this, Bhattacharyya, Sen , and Korschum(2008) found that CSR activity and the extent investment can fulfill employees self enhancement, work life integration, reputation shield and bridge to company needs which leads to internal outcomes like pride in the company, job satisfaction , commitment and engagement to the organization. This is related to the Saks (2006) employee engagement approach.

Vida Skudiene and VilteAuruskeviciene(2012), suggested that CSR (both internal as well as external ) activities positively correlate with employee motivation and engagement to the work.. They also suggested that CSR initiatives like ensure equitable wage system, create favorable psychological climate at work, engage employees in open, honest and flexible communication, involve more often employees into decisions-making processes, and foster personal and career development culture in the organization motivate employees. The employees to feel like a part of their company and more emotionally engaged into CSR initiatives and feel stronger affiliation with the company consequence employees are more likely to trust their company, feel the support, perceive high quality exchange relationships with the company and its management, feel pride and affiliation, and, thus, behave in a similar way which is beneficial for the company. Rupp, Shao, Skarlicki, Paddock, Kim, \&Nadisic , (2018) from growing evidence of employee CSR perception that CSR relate positively to employee work engagement.

The above stated background can be appropriate for the following hypothesis

H5 Company's CSR activities has significant relationship with employee engagement

\subsection{Data collections and Sample}

Table-4:Sample profile of the respondents (Descriptive Statistics)

\begin{tabular}{|c|c|c|c|}
\hline Items & Classification & Frequency & $\%$ \\
\hline Gender & $\begin{array}{l}\text { Male } \\
\text { Female } \\
\mathrm{N}\end{array}$ & $\begin{array}{l}203 \\
147 \\
350 \\
\end{array}$ & $\begin{array}{l}58 \% \\
42 \% \\
100 \% \\
\end{array}$ \\
\hline Degrees & $\begin{array}{l}\text { Bachelors } \\
\text { Masters } \\
\text { Bachelor with professional degrees } \\
\text { Masters with professional degrees }\end{array}$ & $\begin{array}{c}36 \\
206 \\
77 \\
31 \\
\end{array}$ & $\begin{array}{l}10.28 \% \\
58.86 \% \\
22 \% \\
8.86 \% \\
\end{array}$ \\
\hline Age & $\begin{array}{l}20-29 \\
30-39 \\
40-49 \\
51-59 \\
\text { Over } 60 \\
\end{array}$ & $\begin{array}{c}57 \\
185 \\
66 \\
30 \\
12 \\
\end{array}$ & $\begin{array}{l}16.29 \% \\
52.86 \% \\
18.86 \% \\
8.57 \% \\
3.43 \% \\
\end{array}$ \\
\hline $\begin{array}{l}\text { Number Years performing } \\
\text { Business (Firm) }\end{array}$ & $\begin{array}{l}10-15 \\
16-20 \\
21-25 \\
26-30 \\
30 \& \text { above }\end{array}$ & $\begin{array}{l}0 \\
4 \\
4 \\
1 \\
1\end{array}$ & \\
\hline $\begin{array}{l}\text { Number of Year performing in } \\
\text { this organization (Employees) }\end{array}$ & $\begin{array}{l}1-5 \\
6-10 \\
11-15 \\
16-20 \\
21-25 \\
26 \& \text { above }\end{array}$ & $\begin{array}{c}145 \\
107 \\
65 \\
10 \\
20 \\
3\end{array}$ & $\begin{array}{l}41.43 \% \\
30.57 \% \\
18.57 \% \\
2.86 \% \\
5.71 \\
.86 \%\end{array}$ \\
\hline $\begin{array}{l}\text { Average Firm Size (According } \\
\text { to Employee) }\end{array}$ & 3969 & & \\
\hline
\end{tabular}

From: Questionnaire

For preparing the article, it has taken two methods -Qualitative and Quantitative. Firstly, for developing conceptual framework, the author has used qualitative method by using annual report of tenselected commercial banks of Bangladesh.Secondly, the study adapts the survey methods targeting employees of ten public commercial 
banks of Bangladesh. The main aim of this article is to choose public commercial banks which are operating their business more than fifteen years and which have more than two thousand employees in Bangladesh that were taking different initiatives for CSR activities in FY-2018.

Simona Vinerean, Iuliana Cetena; Luigi Dumitrescu (2013) highlighted that an empirical study of responses from 10 multinational companies regarding their corporate Social responsibility initiatives as away to attract and retain good employees, while providing an appropriate environment for employee satisfaction by constructing a structural equation model meant to expand HR literature and provide direct implications for organization. Also, the author has chosen these banks because these banks have disclosed CSR information in their annual report. Most of the employees of these banks are Executive officer to Senior Executive Vice President.Evidence from the prior research on CSR issues verified that the most active companies in CSR were medium and big companies (Graafland and van de Van, 2006). Based on this finding, thepopulation of the research work was taken from the large commercial banks in Bangladesh which have more than 2000 employees according to annual report 2018 and their average employee size was 3969. The author has prepared 500 questionnaires to collect the data and 360 questionnaires was found from respondent but 350 was found successfully completed for this empirical analysis after excluding incomplete responses.

\subsection{Measures}

The study has chosen the measurement scale and the indicators for this articlewhich was validated and the goal of measuring all the construct variables which were found in previsions studies.All of the measures used in this study were drawn from existing literature and adapted to the context of the current study. The measurement scales were 5-point Likert-type scale ranging from 1(Strongly Disagree) to 5 (Strongly Agree). Some of the items were modified to better fit the context of this study. The survey questionnaire integrated two groups of questions: demographic and main questions. Demographic questions were designed in order to gather information about respondents' characteristics, such as age, gender, period of time worked for a company and number of employees of that bank \& time period a company operates their business in the sector from their annual report-2018. The main body of the questionnaire has been adapted fromMaignan\& Ferrell, (2001). From the 17 items Utrecht Work Engagement Scale (Schaufeli et.al. 2002, 2006) the author has chosen 4 items based on data reliability. In order to receive the information how the respondents understand CSR based on CSR activities were given: ethical responsibilities, legal responsibilities, economic responsibilities, and philanthropic responsibilities. The second question asked respondents' opinion about the reasons for companies to engage in CSR activities.

\subsection{Data analysis}

In resent literature of social sciences, structural equation modeling has gained considerable popularity (Bentler and Dudgeon, 1996) and showed measurement errors to estimate the modeled path coefficients. For achieving the objectives of the study, SEM analysis was adopted to examine the relationship between Carroll's CSR Model and Employee engagement. The author has adopted two step analysis based on Anderson and Gerbing's (1988). First step is to assess the adequacy of the measurement model by using the Confirmatory Factor Analysis (CFA) and second is to confirm the structural model based on Structural Equation Model (SEM) analysis. The author has done firstly CFA byAMOS, Convergent validity and discriminant validity by Excel, and last of all SEM by AMOS.

\subsection{Measurement ModelAnalysis}

Thearticle has conducted CFA model to test for the eminence and satisfactoriness of the measurement model by investigating reliability, convergent validity, and discriminant validity which was supported in literature (Anderson and Gerbing, 1988).First the studyhas tested the convergent validity and discriminant validity. From table-5 and table-6, shown that reliability, convergence validity anddiscriminant validity is achieved.

For achieving internal consistency or reliability the author has used most widely criterion Cronbach's $\alpha$, (Cronbach, 1951).In the table-6, descriptive statistics, correlation matrix, and Cronbach's $\alpha$ are described and shown that all pair wise correlations of the studied construct are statistically significant at $\alpha=0.01$ level where correlations among the construct was ranged from 0.30 to 0.62 . From the measurement model, the reliability of the scale is confirmed with the coefficient alpha higher than the recommended level of 0.07 ( Nunnally, 1978).

In table-5, the studyhas found that convergent validity is achieved by assessing Average Variance Extraction (AVE) and Composite reliability (CR). Convergent validity is the degree to which scores on a test correlate with scores on other tests that are designed to assess the same construct. From Anderson and Gerbing(1988), it was suggested that convergent validity can be tested from the measurement model where composite reliability will be all above 0.7 and AVE were will be all above 0.5 then the measurement items were reliable and Valid.... So, it can be said that, the measurement model is reliable and valid under this situation.

Furthermore, it has analyzed the discriminant validity for the measurement model andfound that all the values (e.g. the square root of the average variance extracted) in the crossways are greater than the values in their particular rows and columns (Fornell and Larcker, 1981). That means, discriminant validity shows the degree of 
correlation among the construct and the correlation between different construct should be low (Chen, M.-F., 2015). So, the model is statistically significant and achieved discriminant validity among the construct.

Table-5: Convergent validity and Discriminant validity Measurement

\begin{tabular}{|c|c|c|c|c|c|c|c|c|}
\hline & $\begin{array}{c}\text { Composite } \\
\text { Reliability }(\mathrm{CR})\end{array}$ & $\begin{array}{c}\text { Average } \\
\text { Variance } \\
\text { Extraction(AVE) }\end{array}$ & CSR & $\begin{array}{l}\text { Philanthropic } \\
\text { Responsibility }\end{array}$ & $\begin{array}{c}\text { Legal } \\
\text { Responsibility }\end{array}$ & $\begin{array}{c}\text { Economical } \\
\text { Responsibility }\end{array}$ & $\begin{array}{c}\text { Employee } \\
\text { Engagement }\end{array}$ & $\begin{array}{c}\text { Ethical } \\
\text { Responsibility }\end{array}$ \\
\hline $\begin{array}{c}\text { Corporate } \\
\text { Social } \\
\text { Responsibility }\end{array}$ & 0.739 & 0.506 & 0.640 & & & & & \\
\hline $\begin{array}{l}\text { Philanthropic } \\
\text { Responsibility }\end{array}$ & 0.720 & 0.562 & 0.422 & 0.602 & & & & \\
\hline $\begin{array}{c}\text { Legal } \\
\text { Responsibility }\end{array}$ & 0.775 & 0.610 & 0.470 & 0.408 & 0.640 & & & \\
\hline $\begin{array}{l}\text { Economical } \\
\text { Responsibility }\end{array}$ & 0.754 & 0.506 & 0.444 & 0.262 & 0.453 & 0.711 & & \\
\hline $\begin{array}{c}\text { Employee } \\
\text { Engagement }\end{array}$ & 0.745 & 0.595 & 0.163 & 0.022 & 0.136 & 0.050 & 0.703 & \\
\hline $\begin{array}{c}\text { Ethical } \\
\text { Responsibility }\end{array}$ & 0.757 & 0.539 & 0.180 & 0.482 & 0.558 & 0.361 & 0.125 & 0.589 \\
\hline
\end{tabular}

Note: The square root of the AVE represents in diagonals while the correlations representin the off diagonals

Table-6: The descriptive statistics, correlation matrix, and internal reliability

\begin{tabular}{|l|l|l|l|l|l|l|l|l|}
\hline & Mean & Standard Deviation & & & & & & \\
\hline CSR & 4.0394 & .50671 & $\mathbf{( . 7 1 8 )}$ & & & & & \\
\hline Philanthropic & 3.5133 & .81073 & 0.404 & $\mathbf{( . 8 7 )}$ & & & & \\
\hline Legal Responsibility & 3.4779 & .51631 & 0.445 & 0.408 & $\mathbf{( . 7 8 )}$ & & & \\
\hline Economic responsibility & 3.4681 & .59464 & 0.459 & 0.383 & 0.34 & $\mathbf{( . 8 5 )}$ & & \\
\hline Employee Engagement & 3.9528 & .55164 & 0.406 & 0.365 & 0.33 & 0.43 & $\mathbf{( . 7 0 9 )}$ & \\
\hline Ethical Responsibility & 3.9796 & .69734 & 0.441 & 0.342 & 0.466 & 0.327 & .62 & $\mathbf{( . 8 9 )}$ \\
\hline
\end{tabular}

Note: Cronbach's $\alpha$ value are shown in diagonals.

In table-7, it has showed that different goodness of fit criteria for acceptability of each model along with chisquare test. Joreskog and Sorbom (1996) suggested that Chi-square is perceptive for sample size and further it is necessary to evaluate different goodness of fit for acceptability ofeach model fits the data adequately. So, the article has tested chi-square and got the CMIN/ DF result is below 3 which are considered as satisfactory (Marsh and Hau, 1996).Further, it has found that RMSEA and RMR are less than .08 which is satisfactory; GFI, AGFI, CFI, and NFI are greater than .90 which is accepted as satisfactory as the standard of model fitting (Marcoulides and Schumacker's,1996).

Table-7: Fit indices of measurement model and structural model

\begin{tabular}{|l|c|}
\hline \multicolumn{1}{|c|}{ Fit Indices } & Measurement model and Structural Model \\
\hline Chi-square value & 341.279 \\
\hline Degrees of freedom & 194 \\
\hline CMIN/DF & 1.759 \\
\hline Root mean squared error approximation (RMSEA) & .037 \\
\hline Root mean square residual (RMR) & .042 \\
\hline Goodness-of-fit index (GFI) & .947 \\
\hline Adjusted goodness-of-fit index (AGFI) & .931 \\
\hline The comparative-fit-index (CFI) & .930 \\
\hline The normed-fit index (NFI) & .900 \\
\hline
\end{tabular}

\subsection{Structural Equation Model analysis}

In this article, structural equation model has used to find out the casual relationship among different constructs (Sang, Lee, \&Lee, 2010). In table-7 and table-8, shown path coefficient and t-value (loading and significance) for indicating how well data are supported and various indices are adopted to assess the acceptability of model fits the data satisfactorily. The result of the Structural Equation model is satisfactory for each construct according to Marsh and Hau, (1996). This result is found from the SPSS-23 AMOS output.

The results of the analysis reveal that CSR is positively related to philanthropic responsibilities with $\beta=.13$ and $p$-value $=0.000<0.01$. CSR is positively related to legal responsibilities with $1 \beta=.27$, $p$-value $=0.000<0.01$; Ethical responsibilities has significant impact on $\operatorname{CSR}$ with $\beta=.17$, p-value $=0.003<.01$; Economical responsibilities also has significant influenced on CSR with $\beta=.22$, p-value $=0.005<.01$, and lastly, Companies total CSR activities is positively related with $(\beta)=.18, p$-value $=0.002<0.01)$. Therefore, it can be said that philanthropic responsibilities, ethical responsibilities, economical responsibilities, and legal responsibilities are positively related with companies total CSR initiatives and last of all, companies total CSR directly associated with employee engagement. Furthermore, these results showed hypothesis H1, H2, H3, H4 and H5. 
Table-8: The path coefficients of the structural model

\begin{tabular}{|c|c|c|c|c|c|}
\hline Hypothesis & Relationship & $\begin{array}{c}\text { Standardized } \\
\text { Estimates( } \boldsymbol{\beta})\end{array}$ & $\begin{array}{c}\text { t-value } \\
(\mathbf{C . R})\end{array}$ & $\begin{array}{c}\text { Tested } \\
\text { p-value }\end{array}$ & Decision \\
\hline H1 & CSR<--Philanthropic & .13 & 3.40 & $* * *$ & Supported \\
H2 & CSR<-- Legal & .27 & 3.45 & $* * *$ & Supported \\
H3 & CSR<--Ethical & .17 & 3.00 & .003 & Supported \\
H4 & CSR<--Economical & .22 & 2.80 & .005 & Supported \\
H5 & CSR Employee Engagement & .18 & 3.16 & .002 & Supported \\
\hline
\end{tabular}

Note: $p$-value $<.01$

\subsection{Discussion of the findings}

After the review of different prior research work, it is revealed that most of the research work on CSR is conducted in the developed countries. The result of their findings is more lucid and consistent. Side by side, it can be stated that very limited empirical work revealed a significant incoherent with the developed countries like Bangladesh. Motivated from the different prior research work, this studyhas assessed the effect of Carroll's four CSR dimensions oncompany'stotal CSR initiatives and employee engagement to fill the present breach of CSR. It has found that CSR has positive impact on employee engagement. This study will help management bodies of the bank to enhance their CSR activities to engage their talent pool for managing future competitive world. There are 62 banks in Bangladesh operating their business and these is one big challenge of management to engage their talent pool for betterment of the organization.

From this empirical study on private commercial banks employees of Bangladesh,the findings showed that economic responsibilities, legal responsibilities, ethical responsibilities, and philanthropic responsibilities are positively associated with company'stotal CSR initiatives.Aguilera, et.al, (2007) stated that organizations alliedwith in total social responsibilities are accepted as fair organization.From the first hypothesis,it has found that companies CSR activities is influenced by philanthropic activities of an organization. Previous different studies have also foundthat philanthropic responsibilities have positive influenced on company's CSR (Esmaeelinezhad, Boerhannoeddin, and Singaravello, 2015; Lin, 2010; and Rego, Leal,Cunha,Faria, and Pinho, 2010). Based on these selected banks of Bangladesh, it is proved that companies have maintainedphilanthropic responsibilities for saving natural resources, caring for poverty alleviated people, making affiliation with nonprofit organization for development of education, health, culture and social development, and sports.

Secondly, it has found positive impact on CSR by economic responsibilities of an organization. But some researcher has found negative relationship between these two contracts. (Esmaeelinezhad, Boerhannoeddin, and Singaravello, 2015). In the perspective of Bangladesh, based on commercial banks' employees, it has positive impact on CSR. From the SIT, when company achieve high profit, they can share profit to employees, invest in the market and create greater employability, enhance its reputation, employee feel self -confidence and boost up self esteem by a part of an organization; they can fulfill their belonging need (Turban ,at al, 1997). Economic responsibility can create positive impact on CSR responsibilities for engaging worker in the organization. It brings not only advantages for shareholder but also for employee. Employees have a propensity to trust and believe the organization; enjoy more bonuses that is advantage of employees for increasing the profit of organization, in addition to this, Weitzman Theory (1986) suggested that profit sharing firm have grater employment immovability than non-profit giving out organization. by enhancing extra jobs, bonus, security, and benefits.And Carroll (1979) delineated is a responsibility that is economic in nature, entailing for example providing a return on investment to owners and shareholders; creating jobs and fair pay for workers; discovering new re-sources; promoting technological advancement, innovation, and the creation of new products and services. Business from this perspective is the basic economic unit in society and all its other roles are predicated on this fundamental assumption (Carroll,1979).

From the third hypothesis it has also found that ethical and legal responsibility has positive impact on CSR activities. Based on Herzberg (1966) motivation -hygiene theory, without hygiene factors (secuirity, working conations, payment, personal life, status, and ethical practices) dissatisfaction is aroused in the employees.Last of all, company's total CSR has the strongest impact on employee engagement. Total aspects of CSR have greater impact on individuals work engagement (Backhaus, Stone, Heiner,2002;Greening and Turban, 2000, Ferreira and Oliveira, 2018; Chaudhary, R., 2018). This article carries valuable implications for corporate contact heading for employees. These total CSR perceived as organizational social support that create the trust of the employees on their employers and enhance employee work attachment (Saks, 2006).

\subsection{Conclusion}

Company's CSR functions is one of the main domains in the banking industry in Bangladesh after the mandatory rules provided by Bangladesh bank, the central bank of Bangladesh for all the schedule banks in Bangladesh. The banks must contribute certain percentage from their net profit before tax in CSR activities (Bangladesh Bank, 
2018). CSR is playing a significant role for creating organization reputation, brand values, employee shield, and that motivated employees to engage them in the organization. Desired organizational outcome is the result of employee engagement that is the mental, demonstrative and social state the of employees (Shuck and Wollard, 2010).

\subsection{Managerial Implications}

Based on the empirical study results, it can be provided several commendations for management of the banks, First, the study revealed that company's philanthropic responsibility, ethical responsibility, economicresponsibility, and legal responsibility named as a company'stotal CSR. Management of the banks can give more concentration on these responsibilities in order to enhance their company reputation, brand image, financial growth, and competitive advance. Second, the study result showed that Company's total CSR activities has positive impact on employee engagement. Though, engage worker are the valuable asset for the organization, authority can develop a climate that give priority on different CSR activities in order to create favorable environment for the worker. Thus, management could use this result in order to solve social problem, gives adequate contribution to local communities and socio-economic development, do employees welfare, healthcare, safety standards and modern working environment, development, adjust and revised Salary packages considering industry scenario,provides Comprehensive Training and other development program for development of human capital growth, fulfills the legal obligations,provide full and accurate information to all customers, maintain a comprehensive code of conduct, recognized as a trustworthy company, make organization consistently profitable, maintains high level of efficiency, and lastly, work with company that consistent with maximizing earnings per share.Furthermore,the findingsof the study directed that CSR is a significant tool forgenerating reputation for the organizations and go in concurrence with Hopkins (2008) explanations that CSR influenced to constructive long-term possessions and is a strategic approach to dealing a company.

\subsection{Research limitations and further research}

This study has done on ten commercial banks of Bangladesh therefore, further research can be done on the extended number of banks. Moreover, the study was directed on annual report -2018 and 350 employees Future research can be done on extended number of employees and banks of Bangladesh.

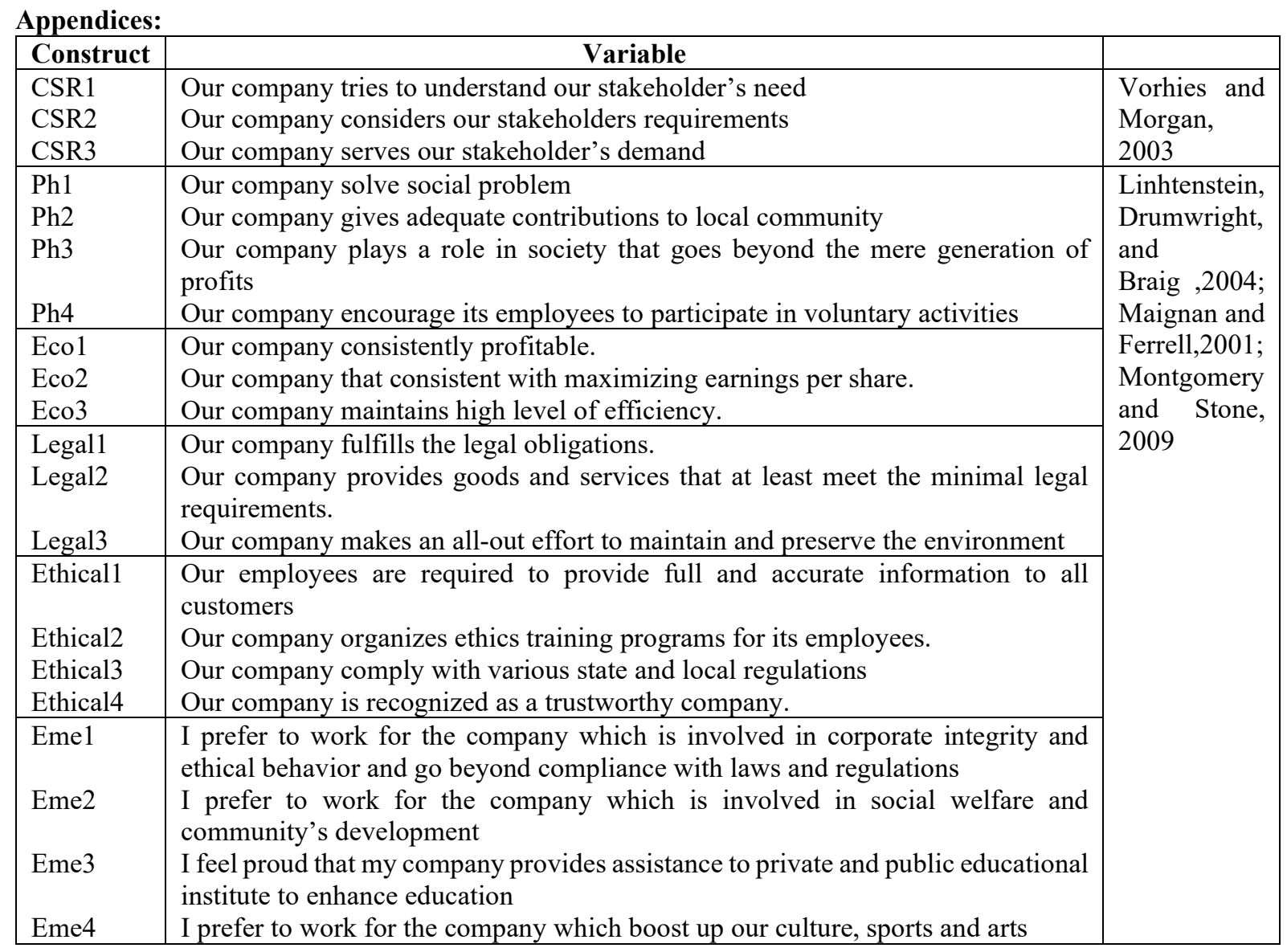




\section{References}

1. Aguilera, R.V., Rupp, D.E., Williams, C.A. and Ganapathi, J., 2007. Putting the S back incorporate social responsibility: a multi-level theory of social change in organizations,Academy of Management Review, Vol. 32 No. 3, pp. 836-63

2. Anderson, J.C. \&Gerning, D.W. ,1988. Structural equation modeling in practice: a review and recommended two-two step approach, Psychol.Bull.103, pp.411-423.

3. Ashforth,B.E., \&Mael, F.1989. Social Identity Theory and the organization, Academy of Management Review, 20-39

4. Aupperle, K. E., Carroll, A. B. \& Hatfield, J. D., 1985. An Empirical Examination of the Relationship between Corporate Social Responsibility and Profitability. Academy of Management Journal, 28[2], p. 446-463.

5. Bakker, A.B. and Schaufeli, W.B., 2008. Positive organizational behavior: engaged employees in flourishing organizations, Journal of Organizational Behavior, Vol. 29 No. 2, pp. 147-154.

6. Aguilera, R.V., Rupp, D.E., Williams, C.A. and Ganapathi, J, 2007. Putting the S back incorporate social responsibility: a multi-level theory of social change in organizations, Academy of Management Review, Vol. 32 No. 3, pp. 836-63.

7. Bachhaus, K.B.,Stone, B.A., and Heiner, K., 2002. Exploring the Relationship between Internal Corporate Social Performance and Employer Attractiveness, Business and Society,Vol. 41(3), pp.292-951.

8. Bauman C. W. and Skitka L. J., 2012. Corporate social responsibility as a source of employee satisfaction. Research in Organizational Behavior, Vol. 32, pp. 63-86.

9. Bhattacharya, C.B., Sen, S. and Korschun, D.,2008. Using corporate social responsibility to winthe war for talent, MIT Sloan Review, Vol. 49 No. 2, pp. 37-44.Permanent link to this document:

10. Buchanan, L., 2004 .The things they do for love, Harvard Business Review, Vol. 82 No. 12, pp. 19-20.

11. Carroll, A. B., 1991. The Pyramid of Corporate Social Responsibility: Toward the Moral Management of Organizational Stakeholders. Business Horizons, 34, p. 39-48.

12. Carroll, A. B. ,1979. A Three-Dimensional Model of Corporate Performance. Academy of Management Review, 4[4], p. 497-505.

13. Carroll, A. B. ,1983. Corporate social responsibility: Will industry respond to cut-backs in social program funding? Vital Speeches of the Day, 49, p. 604-608.

14. Carroll, A. B., 1991. The Pyramid of Corporate Social Responsibility: Toward the Moral Management of Organizational Stakeholders. Business Horizons, 34, p. 39-48.

15. Carroll, A. B.,1994. Social issues in management research: Experts' views, analysis and commentary. Business \& Society, 33, p. 5-29.

16. Carroll, A. B.,1998. The Four Faces of Corporate Citizenship. Business and Society Review, 100[1], p. 1-7.

17. Carroll, A. B. ,1999. Corporate social responsibility. Business and Society, 38[3], p. 268-295.

18. Carroll, A. B. (2000). Ethical Challenges for Business in the New Millennium: Corporate Social Responsibility and Models of Management Morality. Business Ethics Quarterly, 10[1], p. 33-42.

19. Carroll, A. B. (2004). Managing Ethically with Global Stakeholders: A Present and Future Challenge. Academy of Management Executive, 18[2], p. 114-120.

20. Carroll, A.B., andShahana, K.M. (2010), "The business case for corporate social responsibility: a review of concepts, research, and practice", International Journal of Management Reviews, Vol.12. No.1, pp.85-105.

21. Crane, A. \& Matten, D. (2004). Business Ethics. Oxford: Oxford University Press.

22. Chen,M.-F., 2015. Extended the theory of planned behavior model to explain people's energy savings and carbon reduction behavioral intentions to mitigate climate change in Taiwan-moral obligation matters, Journal of cleaner Production, pp.1-8

23. Cochius, T., 2006.Corporate social responsibility in Dutch SMEs: motivation and CSR stakeholders", thesis, Maastricht University, Maastricht.

24. Czarnowsky, M. (2008), Learning's Role in Employee Engagement: An ASTD Research Study, American Society for Training \& Development, Alexandria, VA.

25. Coombs, T. W. and Holladay, S.J., 2012. Managing Corporate Social Responsibility: A communication Approach", Oxford, Uk: Wiley Black Well.

26. Dutton,J.E., Dukerich J. M., \&Harquail, C.V.,1994.Organizational image and member identification”, Administrative Science Quarterly, pp.239-263.

27. Esmaeelinezhad, O., Boerhannoeddin, A.B., and Singaravello, K., 2015.The effects of Corporate Social Responsibility on Employee Engagement in Iran, International Journal of Academic Research in Business and Social Science, Vol. 5, pp.261-276

28. Fleming, J.H. and Asplund, J. (2007), Human Sigma, Gallup, New York, NY.

29. Friedman, M. (1970). The Social Responsibility of Business Is to Increase its Profits, New York Times, p. 122-126.

30. Graafland, J. and van de Van, B., 2006.Strategic and moral motivation for corporate social responsibility", 
Journal of Corporate Citizenship, Vol. 22, pp. 111-23.

31. Harter, J.K., Schmidt, F.L. and Keyes, C.L.M., 2003.Wellbeing in the workplace and its relationship to business outcomes: a review of the Gallup studies, in Keyes, C.L. and Haidt, J. (Eds), Flourishing: The Positive Person and the Good Life, American Psychological Association, Washington, DC, pp. 205-224

32. Heslin, P.A. and Ochoa, J.D., 2008.Understanding and developing strategic corporate socialresponsibility", Organizational Dynamics, Vol. 37 No. 2, pp. 125-44.

33. Jamali, D.,\&Mirshak, R. (2007).Corporate Social Responsibility (CSR): theory and practice in a developing country context, Journal of Business Ethics, Vol.72(3), pp.243-262.

34. Joreskog, K.J., and Sorbom, D., (1996).LISREL8: User's reference guide, Scientific SoftwareInternational.

35. Lee, M.D.P.,(2008).A review of the theories of the corporate social responsibility :its evolutionary path and the road ahead, International Journal of Management Review,Vol.35(3/4)pp.457-484

36. Lichtenstein, D. R., and Drumwright, M.E., (2004). The effects of the perceived fit between corporate

37. Lin, C.-P.,(2010). Modeling corporate citizenship , organizational trust, and work engagement based on attachment theory .Journal of Business Ethics, Vol.94(4),pp.517-531.

38. Longo, M., Mura, M. and Bonoli, A. (2005). Corporate social responsibility and corporateperformance: the case of Italian SMEs. The International Journal of Effective Board Performance, Vol. 5 No. 4, pp. 28-42.

39. Locke, E.A. 1997. The motivation to work: what we know'. In Maehr, M.L. and Pintrich, P.R. (Eds.), Advances in Motivation and Achievement, Vol. 10: 375-412. Greenwich, CT: JAI Press.

40. Lee, C.-K., Song, H.-J., Lee, H.-M., Lee, S. \& Bernhard, B. J. (2013) "The impact of CSR on Casino employees' organizational trust, job Satisfaction, and Customer orientation: An Empirical examination of responsible gambling", International Journal of Hospitality Management, Vol. 33, pp.406-415. http://dx. Doi.org/10.1016/j.ijhm.2012.10.011.

41. Madsen, H. \&Ulhoi, J. P. (2001). Integrating Environmental and Stakeholder Management. Business Strategy and the Environment, Vol.10 [2], pp. 77-88.

42. Maignan, I., \&Ferrell, O.C. (2001), "Corporate Citizenship as a marketing Instrument -Concepts, evidence, and research directions", European Journal of Marketing, Vol.35 (3/4), pp.457-484.

43. Moon, J. (2002). Corporate Social Responsibility: An Overview. In C. Hartley (Ed.), The International Directory of Corporate Philanthropy, First ed.: 3-14. London and New York: European Publications.

44. Marsh, H.W., and Hau, K.T.( 1996) .Assessing goodness of fit: is parsimony always desirable?J.Exp. Educ., Vol.64,pp-364-390.

45. Sustainability (2004). Gearing Up: From Corporate Responsibility to Good Governance and Scaleable Solutions. London: Sustainability.

46. Maslach, C., Schaufeli, W.B. and Leiter, M.P. (2001), "Job burnout”, Annual Review of Psychology, Vol. 52, pp. 397-422.

47. Melynyte,O.\&Ruzevicius, J. (2008). Framework of links between corporate social responsibility and human resource management, Forum ware international, Vol.1, pp.23-34

48. Montgomery, C., and Stone, G, (2009). Revisiting consumer environmental responsibility: A five nation cross-cultural analysis and comparison of consumer ecological opinions and behaviors, International Journal of Management and Marketing Research, Vol.2(1), pp.35-58

49. Nunnally, J.C., (1978). Psychometric Theory, Second ed. McGraw-Hill, New York.

50. Ologbo, A.C., \& Sofian, S. (2013). Individuals and Organizational Factors of Employee Engagement on Employee Work Outcomes", International Journal of Business and Behavioral Science, Vol.3(3).

51. Pablo Rodrigo and Daniel Arenas (2008). Do Employees Care About CSR Programs? A Typology of Employees According to Their Attitudes, Journal of Business Ethics (2008) 83:265-283, Springer-2007

52. Pinkston, T. S. \& Carroll, A. B. (1994). Corporate Citizenship Perspectives and Foreign Direct Investment in the US. Journal of Business Ethics, 13[3], p. 157-169.

53. Rahman, A. (2013). Evolution of CSR in Bangladesh and Future Challenges, CSRReview, Vol. 10.

54. Rego, A., Leal, S., Cunha, M. P., Faria, J., and Pinho, C., (2010). How the perception of five dimensions of corporate citizenship and their inter-inconsistencies predict affective commitment", Journal of Business Ethics, Vol.94(1), pp.107-127.

55. Richa Chaudhary, (2017). Corporate social responsibility and employee engagement: can CSR help in redressing the engagement gap?", Social Responsibility Journal, Vol. 13 Issue: 2, pp.323-338, https://doi.org/10.1108/SRJ-07-2016-0115

56. Redington, I., (2005). Making CSR Happen: The Contribution of People Management, London, The Chartered Institute of Personnel and Development (CIPD).

57. Rupp, Deborah E. Shao,R., Skarlicki,Daniel P., Paddock,E. L., Kim, Tae-Yeo, \&Nadisic, ,T. (2018). Corporate social responsibility and employee engagement: The moderating role of CSR-specific relative autonomy and individualism”, Willy-Journal of Organizational Behavior, SPECIAL ISSUE Received: 28 June 2016 Revised: 5 March 2018 Accepted: 5 March 2018DOI: 10.1002/job.2282 
58. Saks, A.M. (2006). Antecedents and consequences of employee engagement”, Journal of Managerial Psychology, Vol. 21 No. 7, pp. 600-619

59. Sang, S., Lee, J.-D., \& Lee, J. (2010). E-government adoption in Cambodia: a partial least squares approach". Transforming Government:People,Process, and Policy, Vol.4 (2), pp.138-157.

60. Shuck,M.B. and Wollard, K., (2010). Employee Engagement and HRD: A seminal review of the foundations, Human Resource Development Review, Vol.9(1), pp. 89-110

61. Strautmanis, J.(2008). Employees' value orientations in the context of corporate social responsibility" Baltic Journal of Management, Vol.3(3), pp.346-58

62. Turban, D.B. \& Cable, D.M., (2003). Firm reputation and applicant pool characteristics, Journal of Organizational Behavior, No.24, pp.733-51.

63. Turban, D.B.\&Greening, D.W. (2003). Corporate social performance and organizational

64. Van Marrewijk, M. \&Werre, M. (2002). Multiple Levels of Corporate Sustainability. Unpublished.

65. Vorhies, D.W. and Morgan, N.A. (2003). A configuration theory assessment of marketing organization fit with business strategy and its relationship with marketing performance, Journal of Marketing, Vol.67(1), pp.100-115

66. Visser, W. (2005). Revisiting Carroll's CSR Pyramid-An African Perspective,

67. Van Marrewijk, M. (2003). Concepts and Definitions of CSR and Corporate Sustainability: Between Agency and Communion. Journal of Business Ethics, 44, p. 95-105.

68. Vida Skudiene and VilteAuruskeviciene, (2012). The contribution of corporate social responsibility to internalemployee motivation, Baltic Journal of Management, Vol. 71, pp. $49-67$

69. Viswesvaran, C., Deshpande, S.P.\& Milan, C. (2004). Intrinsic versus extrinsic goal contents in selfdetermination theory: another looks at the quality of academic motivation, Educational Psychologist, Vo.41(4), pp.19-31

70. Wheeler, D., Colbert, B. \& Freeman, R. E. (2003). Focusing on Value: Corporate Social Responsibility, Sustainability and a Stakeholder Approach in a Network World. Journal of General Management, 28[3], pp. $1-28$.

71. World Business Council for Sustainable Development. 1999. Corporate Social Responsibility: Meeting Changing Expectations. World Business Council for Sustainable Development: Geneva

72. Wheeler, D., Colbert, B. \& Freeman, R. E. (2003). Focusing on Value: Corporate Social Responsibility, Sustainability and a Stakeholder Approach in a Network World. Journal of General Management, 28[3], pp. $1-28$.

73. Wagner, R. and Harter, J.K. (2006), 12: The Great Elements of Managing, The Gallup Organization, Washington, DC. https://doi.org/10.1108/SRJ-07-2016-0115.

74. Windsor, D.: 2001. The Future of Corporate Social Responsibility, The International Journal of Organizational Analysis, Vol.9(3),pp. 225-256. 